\title{
INTELLIGENT INSTRUMENT TO FACILITATE DECISION MAKING IN THE EVALUATION OF SOIL RESISTANCE TO ROOT PENETRATION
}

\author{
Ladislau Marcelino Rabello*; Paulo Estevão Cruvinel \\ Embrapa Instrumentação Agropecuária, R. XV de Novembro - 1452, C.P. 741, 13560-970 - São Carlos, SP - \\ Brasil. \\ *Corresponding author <rabello@cnpdia.embrapa.br>
}

\begin{abstract}
This contribution introduces an instrument for decision-making in agricultural processes based on the measurements and mapping of soil resistance to root penetration. Its development was based on a new and advanced instrumentation tool, enabling in almost real-time to acquire the necessary information for spatial variability analysis of plant root penetration resistance in soils, due to natural or artificial soil compaction processes, i.e., not only for an area of soil but also for a soil profile. The system allows soil resistance assays for both laboratory and agricultural fields. Moreover, the development focused on an intelligent instrumentation concept, as well as a microprobe $\left(30^{\circ}\right.$ for the spire angle, $1,6 \mathrm{~mm}$ for the base diameter, and $30 \mathrm{~mm}$ of total length), with a strain-gage transducer sensor. Results have shown that measurements of soil resistance to plant root penetration can be performed up to the limit of (483.47 \pm 0.69$) \mathrm{N}$, with a resolution of $15.4 \mathrm{~N}$. Additionally, the versatility of the system is verified for soil resistance data collection and its interpretation to root plant penetration, since they can be presented in table formats, one-dimensional graphs, two-dimensional and threedimensional maps. Therefore, this system enables users to obtain a quick interpretation of the soil aggregation state in agricultural areas.

Key words: agricultural instrumentation, intelligent systems, signal processing, soil microprobe, soil penetrometer

\section{INSTRUMENTAÇÃO INTELIGENTE PARAAUXILIO À TOMADA DE DECISÃO NAAVALIAÇÃO DARESISTÊNCIADO SOLO ÀPENETRAÇÃODE RAÍZES}

\begin{abstract}
RESUMO: Neste trabalho é apresentado um instrumento para auxilio à tomada de decisão em processos que envolvem avaliações da resistência do solo à penetração de raízes. Seu desenvolvimento fundamenta-se na concepção de uma nova ferramenta instrumental avançada, que viabiliza em tempo quase real informações para análise da variabilidade espacial da resistência do solo à penetração de raízes, tanto para área como para perfil, devido aos processos de compactação natural ou artificial do solo. Ensaios para a medida da resistência do solo à penetração de raízes podem ser realizados tanto em ambiente laboratorial como diretamente em campo agrícola. Para o desenvolvimento utilizou-se o enfoque da instrumentação inteligente, bem como uma microsonda (ângulo de cone de $30^{\circ}$, diâmetro de base de 1,6 mm e comprimento total de $30 \mathrm{~mm}$ ) sensoriada por célula de carga. Resultados mostram que medidas de resistência do solo à penetração de raízes podem ser realizadas até um limite de (483,47 $\pm 0,69) \mathrm{N}$ com resolução de 15,4 N. Adicionalmente, a versatilidade do sistema é verificada para a coleta de dados e interpretação da resistência do solo à penetração de raízes, uma vez que podem ser apresentados na forma de tabelas, gráficos unidimensionais, mapas bidimensionais e mapas tridimensionais. Desta maneira, o sistema possibilita ao usuário uma rápida interpretação sobre o estado de agregação do solo em áreas de cultivo agrícolas.

Palavras-chave: instrumentação agropecuária, sistemas inteligentes, processamento de sinais, microsonda, penetrômetros
\end{abstract}

\section{INTRODUCTION}

The intensive use of soils, in large scale agricultural production, has generated a series of problems including the efficiency of the production capacity
(Lins e Silva, 1999). The quantification of soil compaction can be carried out with instruments called penetrometers (Hanks \& Thorp, 1956), (Duley, 1939), (Morin et al., 1981), (Liu et al., 2006), (Mumkholm et al., 2003), and (Clivate-McIntyre \& McCoy, 2006). 
Soil rigidity measurements stem from the force or resistance that the soil displays against the penetration of a metal probe, generally called penetrometer, (Bradford, 1986). Due to its dimensions, it does not have the necessary precision to measure the degree of soil crust compacting and the quantified force that a seed experiences during germination.Small probes have been used to simulate the penetration force of the roots (Taylor \& Gardner, 1963, Barley et al., 1965, Waldron \& Constantin, 1970, Groenevelt et al., 1984, Grant et al., 1985, Rolston et al., 1991), and also to characterize soil structure in a laboratory setting.

In this study the evaluation of soil resistance to root penetration is given as a function of the agricultural field coordinates. Besides, based on a friendly computational interface, both 2D and 3D real time maps of soil resistance can be obtained, thereby assisting farmers to make decisions.

\section{MATERIALAND METHODS}

The developed system comprises a mechanical module and an automatic microcontrolled module, responsible for the microprobe positioning control for the measurement of soil resistance to root penetration, as well as a central computer responsible for the general management and interface with the user (Figure 1).
The interface with the user is performed by a computer program developed for the following function: communication between the control system and the data acquisition for the central computer to execute the tasks. These tasks consist in receiving the collected data of soil penetration resistance measurements and in organizing the data in a bank for future use.

Data interpretation is supplied to the user in the form of a report, consisting of tables and graphs of the measures in near real time, allowing also the interpretation of the data through charts in bi and tri-dimensional format, which allows the interpretation of spatial and temporal variability of soil resistance to penetration of roots.

\section{Microprobe}

In the development of the microprobe, considering not only the friction force of the components, but also the calculation of soil resistance to root penetration due to soil parameters such as volumetric soil water content $(\theta)$, bulk density $\left(\rho_{s}\right)$ and depth (D), and also considering factors such as the height of the metal microcone (hc) and the measurement of the shaft instrument (ha), the goal was to discover the total mechanical resistance that the soil offers to root penetration (RSPrm). With additional information on the normal surface tension of the soil surface $\left(\sigma_{\mathrm{n}}\right)$, friction coefficient $(\mu)$, semi-angle of the cone point $(\alpha)$, ad-

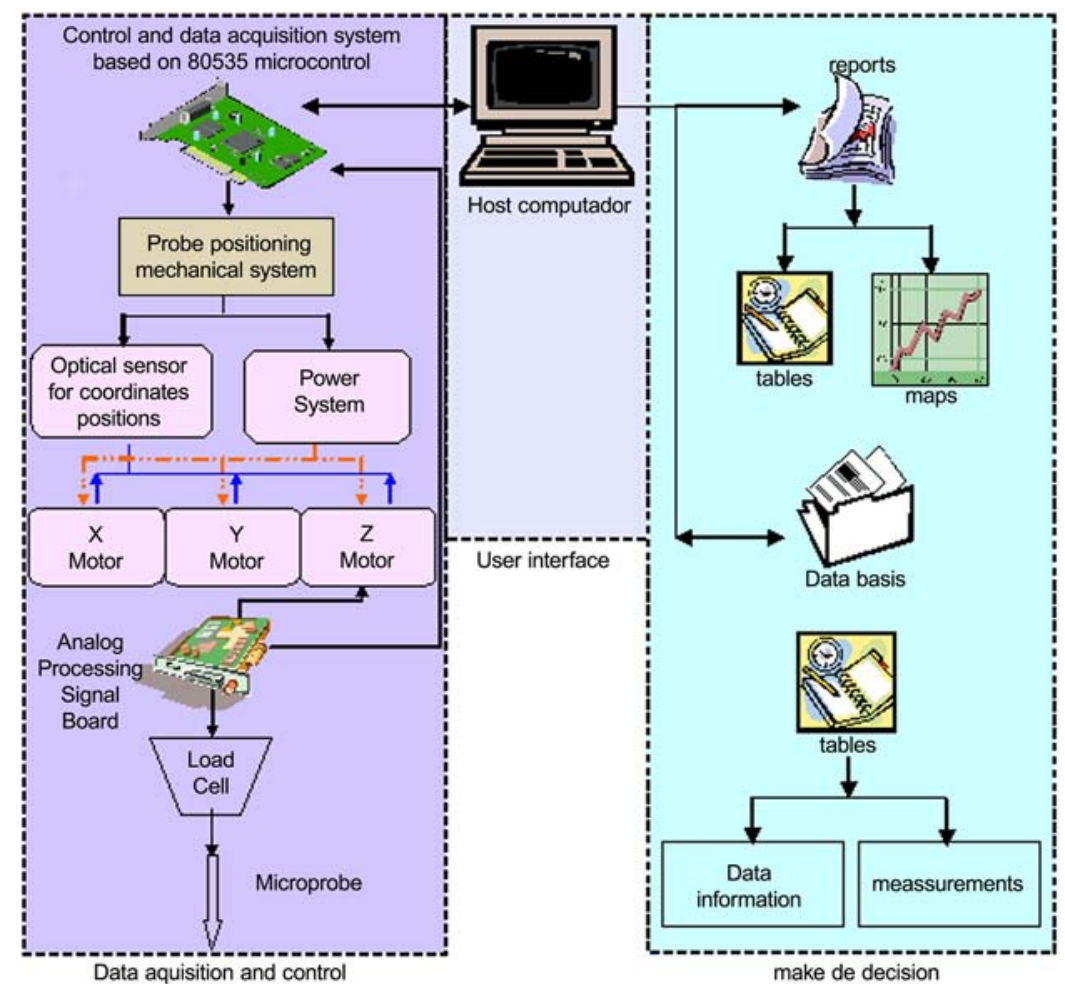

Figure 1 - General block diagram of the measurement system for soil resistance to root penetration. 
ditional tangential tension (c $\mathrm{c}_{\mathrm{a}}$ and (microcone) soil penetration resistance (RP), RSPrm is given by:

RSPrm $=6.98 \rho_{\mathrm{s}}^{2}+\left[\left(-1.6210^{-1}\right)+\left(\begin{array}{ll}1.36 & \left.10^{-3}\right)\end{array}\right.\right.$ $\left.\left(h_{a}+R_{c}\left(R P-\sigma_{n} /\left(\left(\mu . \sigma_{n}\right)+c a\right)\right)\right)\right] \cdot \rho_{s}+\left[\left(1.9810^{-1}\right)-(9.20\right.$ $\left.\left.10^{-3}\right)\left(\mathrm{h}_{\mathrm{a}}+\mathrm{R}_{\mathrm{c}}\left(\mathrm{RP}-\sigma_{\mathrm{n}} /\left(\left(\mu . \sigma_{\mathrm{n}}\right)+\mathrm{ca}\right)\right)\right)\right]\left(\theta . \rho_{\mathrm{s}}\right)+\left(9.8010^{-2}\right)$ $\left[h_{a}+R_{c}\left(R P-\sigma_{n} /\left(\left(\mu . \sigma_{n}\right)+c a\right)\right)\right]-\left(2.0010^{-3}\right)\left[h_{a}+R_{c}(R P-\right.$ $\left.\sigma_{\mathrm{n}} /\left(\left(\mu . \sigma_{\mathrm{n}}\right)+\mathrm{ca}\right)\right]^{2}-\left(10.4410^{-3}\right)$

The microprobe was constructed based on described models, using a $1.610^{-3} \mathrm{~m}$ diameter and 0.2 $\mathrm{m}$ length tungsten rod, which resulted in a final probe of $5710^{-3} \mathrm{~m}$ in length and a cone point angle of $30^{\circ}$. The microprobe is connected to the load cell through mechanical chuck, (Rabello, 2003).

\section{Mechanical Module}

The mechanical module is composed of a XYZ table for the spatial localization of the measurement probe of the mechanical resistance to soil penetration. The $\mathrm{XYZ}$ table is sustained by fuses and linear shafts of dislocation localized in a support over the support structure. The XYZ table has two position adjustments to set the sensor, a manual one, only in the direction of the axis $\mathrm{X}$ and an automatic one that identifies it at any coordinate inside the limits of the axis.

The support of the structure consists of a $1.13 \mathrm{~m}$ by $0.52 \mathrm{~m}$ rectangular aluminum frame, comprised by two perforated $\mathrm{U}$ shaped pieces of $1.016 \mathrm{~m} \times 0.127$ $\mathrm{m} \times 0.0635 \mathrm{~m}$ and $0.109 \mathrm{~m}$ in length. These two perforations are joined by two metal bars of $0.52 \mathrm{~m} \times$ $0.12 \mathrm{~m} \times 0.02 \mathrm{~m}$. All of the suspension is sustained by three adjustable legs, with two at each frame extremity and one that is centralized on the opposite side of the two to facilitate the entire leveling of the structure. Inside the structure support, a base was mounted transversally, also made of aluminum, with dimensions of $0.50 \mathrm{~m} \times 0.15 \mathrm{~m} \times 0.075 \mathrm{~m}$. This base is located inside the metal frame and is sustained by two linear shafts with a diameter of $0.02 \mathrm{~m}$,

The microprobe sliding positioning system over the linear shaft is accomplished by using two $0.02 \mathrm{~m}$ linear ball screw bearings. The system movement is possible through a stepper motor mounted together with a ball screw that has $810^{-3} \mathrm{~m}$ per motor step and $0.018 \mathrm{~m}$ in diameter, that transfers the movement to a ball screw nut, which is $10^{-3} \mathrm{~m}$ long. The whole system provides an increase/decrease of $40 \mu \mathrm{m}$ by the motor step in the $\mathrm{X}$ direction. For system maintenance, a steering wheel was placed opposite to the motor to allow manual movement.

In the lower part of the microprobe positioning system, the whole system was mounted for the movement of the $\mathrm{Y}$ and $\mathrm{Z}$ axis. The movement in the direction of $\mathrm{Y}$ is made over a linear guide, on a ball screw bearing of step of $510^{-3} \mathrm{~m}$ and with a diameter of 14 $10^{-3} \mathrm{~m}$. The movement using the fuse is made with a ball screw nut of step $510^{-3} \mathrm{~m}$, fixed on the other base that sustains the system movement of the $\mathrm{Z}$ axis.

The movement in the direction of the $\mathrm{Y}$ axis is possible by using a step motor located in one of the linear guide extremities with an increase/decrease of 25 $\mu \mathrm{m}$ per motor step. Attached to the movement car of the $\mathrm{Y}$ axis is a third base that serves to sustain the whole system movement of the microprobe, which is mounted vertically.

The microprobe movement system comprises two aluminum tubes of different diameters; the internal tube has $5010^{-3} \mathrm{~m}$ in diameter and the external $6010^{-3} \mathrm{~m}$, and allows the internal tube to move freely inside the external tube resembling a telescope. The movement takes place using a ball screw of step $510^{-3} \mathrm{~m}$ and diameter of $1410^{-3} \mathrm{~m}$, connected to a ball screw bearing of step $510^{-3} \mathrm{~m}$, which is fastened to the internal tube. In the upper extremity, the ball screw bearing is connected to a step motor. This is responsible for the microprobe movement with an increase/decrease of 25 $\mu \mathrm{m}$ per motor step. A junction box is mounted at the extreme opposite to the motor and is composed of load cells, the microprobe and the load cell electric circuits of the conditioning signal. Figure 2 illustrates the field system.

\section{Electronic Module}

The electronic module is basically composed of: (i) a central micro-controlled unit mounted on a 80535 microcontroller; (ii) a power circuit unit used to feed and convert signals for the step motors; (iii) general

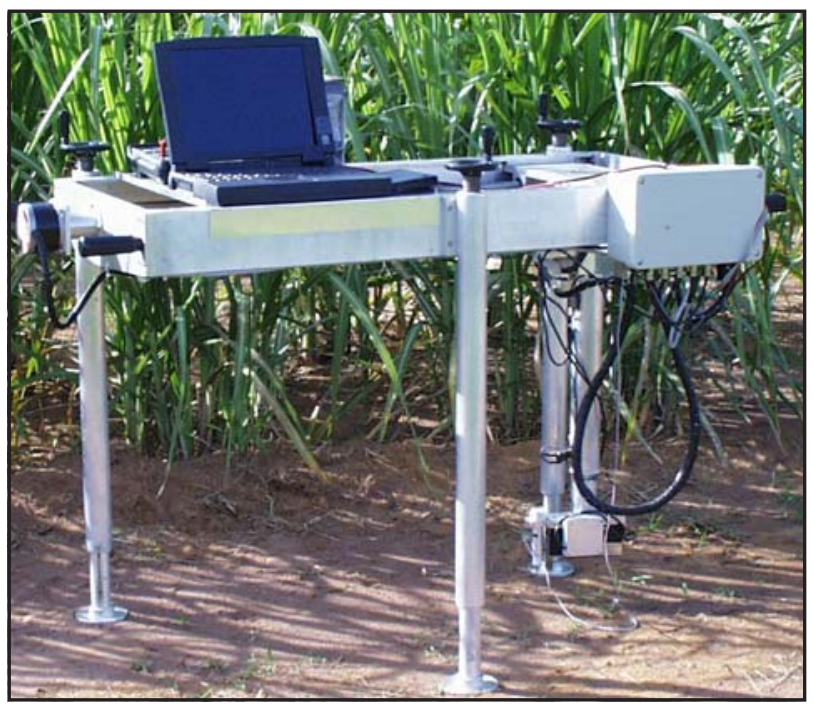

Figure 2 - Photograph illustrating a prototype of the intelligent instrument that captures and facilitates decisions regarding the evaluation of the resistance of soil to root penetration. 
power supply; (iv) positioning systems, composed by step motors; (vi) load cells to operate the microprobe sensor; circuits for electrical signal processing; (vi) a central computer responsible for the system-user interface. The communication with the computer is made through a cable connected to a female DB9 connector, standard RS-232.

The power board circuit makes possible the conversion of digital signals in TTL level from the microprocessor circuit board to the necessary signal levels to control the step motor. Also, the X and Z step motors have the following characteristics: a step angle of $1.8^{\circ}, 200$ steps per complete turn, 98 N.m of locking torque, 6 VDc per 3.1A and the number of wires equal to 6 . The load cell has the following characteristics: $5.0 \mathrm{~kg}$ of capacity and a nominal signal of $2.0 \mathrm{mV} / \mathrm{V}$.

\section{Computational System}

The computer program developed for the system is composed of two subprograms. One of them is resident in the memory of the CPU 80535 program and its function is to receive commands from the external computer in order to execute microprobe positioning tasks. It also acquires data of the mechanical resistance of the penetration and then sends the collected data back to the external computer. The other subprogram is used for the interface with the user and in coordination with the user sends the commands to the 80535 microprocessor. It receives the collected data, organizes, processes and stores it in a data bank, generating respective reports.

In the development of this program for the user interface, the application Win32 was used applying the development environment $C++$ Builder 5 by Borland. The data base implementation used the Borland Data Base Engine to generate the Paradox tables. This type of data-base has the advantage of foregoing a databank system manager but still keeping compatibility with a large range of applications. A practice known as Multithread is used within the capacity of the system Win32 to permit the same application to execute combined codes. The combined system is used to enable monitoring the serial communication port in order to process and store the data received from the data base. The interface permits the user to directly access all the necessary commands to control the system. It can also visualize in nearly real-time the collected measurement data of soil resistance to root penetration in tables and two-dimensional graphs.

Computer program for 2D- and 3D- layer visualization of the soil resistance to root penetration

As an analysis tool, this program allows to read the data recorded in the data bases and from tables that have been created by a former discreet program. Af- ter reading a specific data base or tables the 2D layer visualization tool converts the data into a two-dimensional map per penetration layer. It can visualize the forces of layer penetration in a standard 256 levels of gray.

The images generated from the data collection of the soil resistance to root penetration supplies two-dimensional information by penetration layer of the microprobe. For each analysis, there is a total of 66 separate maps of $0.110^{-3} \mathrm{~m}$ forthe first 40 measurements and $1.010^{-3} \mathrm{~m}$ for the remaining 26. In addition, it is possible to group these $2 \mathrm{D}$ maps in a three-dimensional subsurface layer perspective. The three-dimensional mapping is obtained by interpolating one or various layers between the spaces of each layer.

The interpolation method consists of simulating intermediate data from a known data base. For this process interpolation based on the B-Spline-Wavelets was used (Bradley, 1993); (Donoho, 1993); (Graps, 1995); (Revathy, 2000).

The relationship between the Wavelet Haar $\psi_{H}$ and the function B-Spline of first order is represented by $N_{1}$ :

$\psi_{H}(x)=N_{1}(2 x)-N_{1}(2 x-1)$

and the relationship with the $B$-Spline of the second order $N_{2}$ is given by:

$\psi_{H}(x)=N_{2}(2 x)$

in this mode, the value of $N_{m}$ is given by equation (4):

$N_{m}(k)=\left\{\begin{array}{l}N_{2}(k)=\delta_{k, 1} \quad k \in \mathrm{Z} \\ N_{n+1}(k)=\frac{k}{n} N_{n}(k)+\frac{n-k+1}{n} N_{n}(k-1) \quad k=1, \ldots, n\end{array}\right.$

One can now take the function $B$-Spline $L_{2}$ given by $L_{2}(x)=N_{2}(x+1)$ where $L$ is defined by eq. 5 in order $m$ and with the sequence of coefficients $C_{k}$ such as:

$L_{m}(x)=\sum_{k=-\infty}^{\infty} c_{k}^{(m)} N_{m}\left(x+\frac{m}{2}-k\right)$

A basic Wavelet is defined as:

$\psi_{H}(x)=L_{2}(2 x-1)$

Following this development, one can obtain Wavelets-Splines of superior order, or then, generate spaces of superior order by the relationship:

$V_{j+1}^{(m)}=V_{2 m}^{(m)} \oplus W_{j}^{(m)}, j \in \mathrm{Z}$

where $\oplus$ symbolizes an orthogonal addition, $V$ belonging to the sequence $\left\{V_{i}^{m}\right\}$ generated by the multi reso- 
lution analysis generated by the $B$-Spline of order $m$ and $W$ belonging to $\left\{W_{i}^{m}\right\}$ that is the sequence of orthogonal complementary Wavelet spaces.

The interpolation by B-Wavelets determines the intermediate values between sequences of known points. Different from the estimate, the interpolation not only dislocates the generated curve under the influence of known points, but also makes this curve pass through these points.

In the volumetric visual interface is an area reserved for the volumetric map visualization where are axes that by mouse movement, enable discerning the frontal, sagittal and transverse planes. Together with the volumetric visual area are three bars with a cursor that is used to move the $\mathrm{X}, \mathrm{Y}$, and $\mathrm{Z}$ axes to allow viewing the map cuts of the complementary window interface.

There are also data filters of the threshold that perceive the different values of the soil resistance to the root penetration within the chosen range and use the mouse to initiate rotations and translations above the body of $\mathrm{X}, \mathrm{Y}$, and $\mathrm{Z}$ axes in a way to see the reconstructed object from different angles.

There are two palettes in the middle of the interface; one is a colored spectrum and the other one is in tones of gray, called visible spectrum. In the middle of both ranges there is another one that is used to indicate to the user the threshold range that it intends to analyze in the data base image generator. The color range as well as the tones of gray vary equally inside a scale of 0 to 255 levels. The volumetric interface also represents a small menu that enables accessing the essential control commands in this interface.

\section{Experimental planning to validate and error analysis}

The measurement evaluation tests of soil resistance to root penetration were performed by calibrating the electric signals provided by the microprobe and sensed by a load cell using a $20 \mathrm{~kg}$ weighing scale in the range 0 to $5 \mathrm{~kg}$.

The microprobe was set in the center of the central base of the weighing-machine, making afterwards the system to cause small advances of the microprobe against the scale balance, thereby constantly verifying the dislocation of the weight scale pointer in accordance to the exerted force. Each increment of the microprobe corresponds to an increment of $0.10 \mathrm{~kg}$, divided in the ranges of 0.0 to $1.0 \mathrm{~kg} ; 1.0$ to $2.0 \mathrm{~kg}$; 2.0 to $3.0 \mathrm{~kg} ; 3.0$ to $4.0 \mathrm{~kg}$ and from 4.0 to $5.0 \mathrm{~kg}$. The electric proportional analog signal responsible for the deflection of the weight scale pointer predicts the load cell; it was monitored by a $61 / 2$ digit model 34401A, HP multi-gauge.
The measurement test was organized in two phases in the laboratory and one in the field. For the laboratory trials, two samples were selected. One sample came from a single small soil sample and the other came from a soil block sample in order to measure the profile and spatial variability. To achieve the same objectives, an area was selected for the field tests.

The soil samples from the laboratory tests as well as those from the field were selected from an experi-

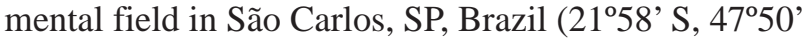
W).

The first sample was collected from a pasture area whose soil is a clayey-textured Hapludox. These samples were extracted using a sample cylinder of 72 $10^{-3} \mathrm{~m}$ internal diameter and $5410^{-3} \mathrm{~m}$ height, containing a soil mass of $403.73 \mathrm{~g}$. The second group of trial samples was collected from an area of a Paleudalf. The samples were collected in blocks of $0.27 \mathrm{~m} \times 0.27$ $\mathrm{m} \times 0.13 \mathrm{~m}$.

Additionally, a third trial was planned with direct measurements under field conditions. The area presents a medium-textured Hapludox located near a sugarcane field.

\section{RESULTS AND DISCUSSION}

The percentage error of evaluation was estimated in the range of $0.0 \mathrm{~kg}$ to $5 \mathrm{~kg}$ (Figure 3). The percentage of errors observed, taking into consideration the medium values presented, were respectively $28.9 \%$ for the range between 0.00 to $0.10 \mathrm{~kg}, 2.2 \%$ for 0.20 to $0.50 \mathrm{~kg}$, and below $1 \%$ for 0.60 to $5.00 \mathrm{~kg}$. The conversion of values was equal to or above $0.16 \mathrm{~kg}$ of the medium percentage error that was below $5 \%$.

The first sample obtained with the sample cylinder was adjusted in the laboratory below the probe and commands of the data acquisition were supplied. Partial results of this measurement are illustrated in Figures 4 and 5 with a respective interface showing the options for table or graph data instructions.

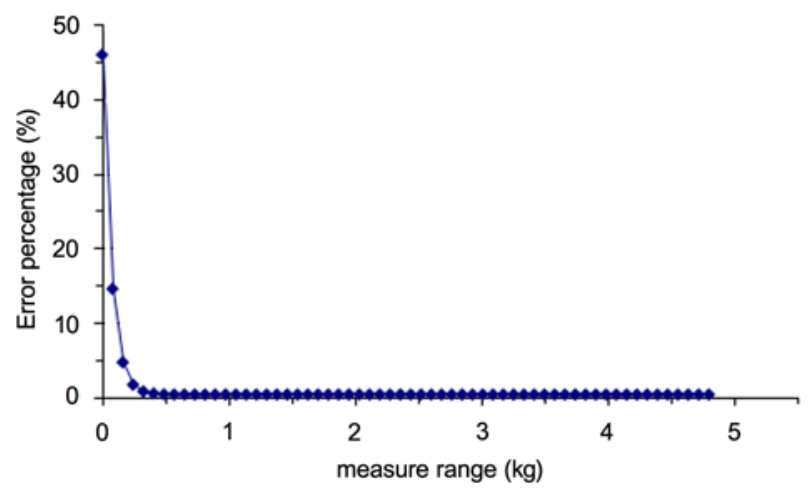

Figure 3 - Percentage Error obtained in the range of $0.0 \mathrm{~kg}$ to 5.0 $\mathrm{kg}$ for the conversion process of the analog signal from the microprobe to the A/D converter word. 


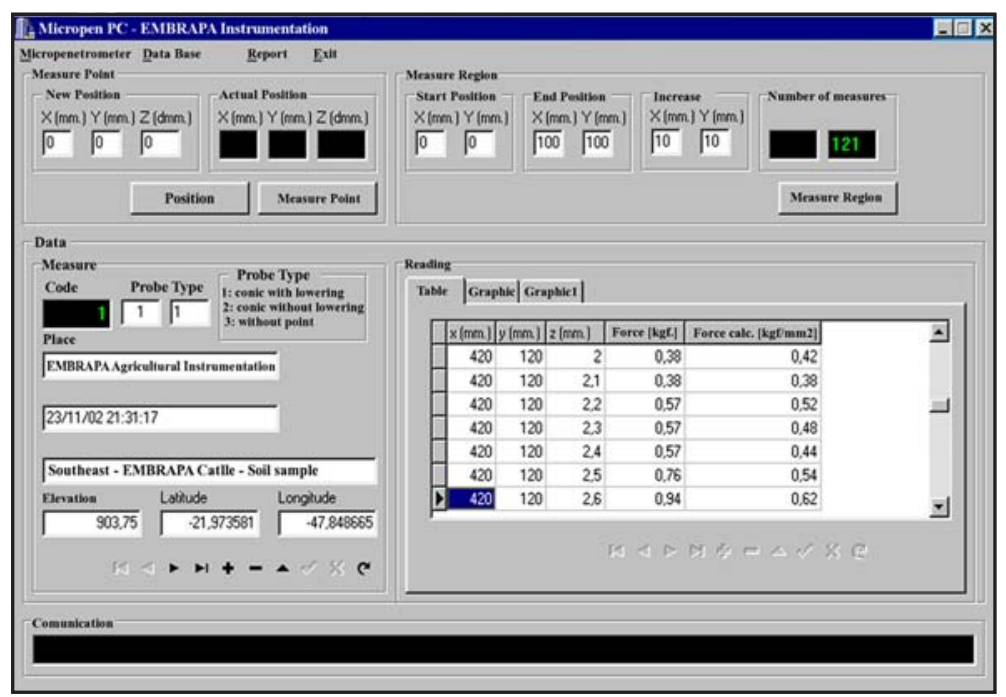

Figure 4 - Interface showing the options of data presentation in the table function.

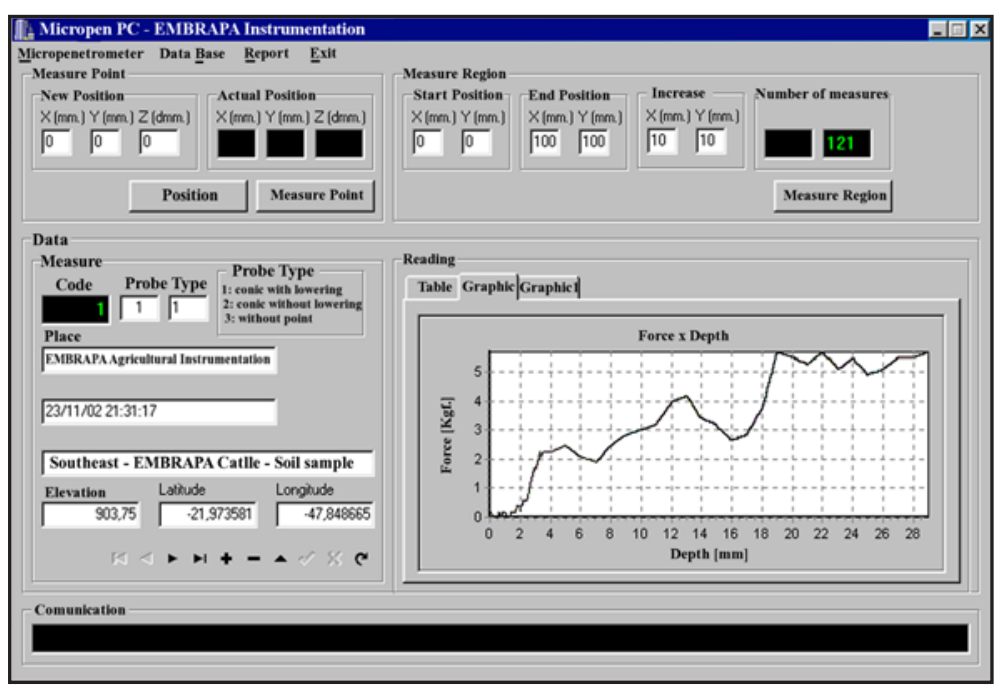

Figure 5 - Interface showing the options of data presentation in the graphic function.

The system was positioned on a single point using the extremity of the block soil sample with coordinates $X=300 \mathrm{~mm}$ and $Y=50 \mathrm{~mm}$, with increases in the directions $\mathrm{X}$ and $\mathrm{Y}$ of $10 \mathrm{~mm}$, and final coordinates of $X=480 \mathrm{~mm}$ and $Y=230 \mathrm{~mm}$, forming a measurement grid of $19 \times 19$, with 66 measurements per point. The trails with the soil block generated a data base with the dimension of 23,826 lines by six columns.

The view of the data of soil resistance to root penetration presented in the table format or one-dimensional graph is difficult given that the data base increases. In these situations, the generation of two-dimensional maps can be a useful tool. The maps illustrate the spatial variability of the soil resistance to root penetration at different depths of the test profiles (Figure 6).

Starting with the two-dimensional maps, the volumetric view of the soil block sample can be obtained with an interpolation of the planned measurements (Figure 7), as well as the respective frontal, lateral and transversal cuts.

In the field tests the instrument was first leveled with the soil surface and then the following instrumentation was utilized: a 12 volt DC car battery with electrical current capacity of $45 \mathrm{Ah}$, used to supplement the electric power of the measuring instrument as well as of the central computer which was a LapTop PC-Compatible, with a 486 microprocessor operating at $200 \mathrm{MHz}$, and $32 \mathrm{M}$ bytes of RAM.

The data collection was conducted in a $0.27 \mathrm{~m} \times$ $0.27 \mathrm{~m}$ area, with a distance variation of $0.015 \mathrm{~m}$ between them. The starting coordinates supplied by the system are indicated in Table 1 . The quantity of data generated with this base of coordinates corresponds to a matrix that is $19 \times 19$ points by 66 levels of depth and that requires a total of 23826 registers. With the 


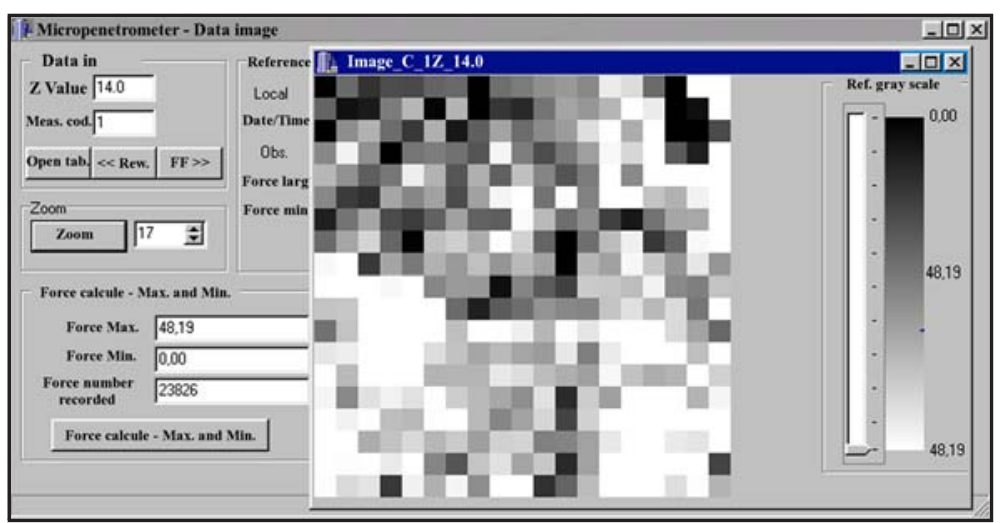

Figure 6 - Visualization of the soil resistance to root penetration in a layer depth of $14.0 \mathrm{~mm}$.

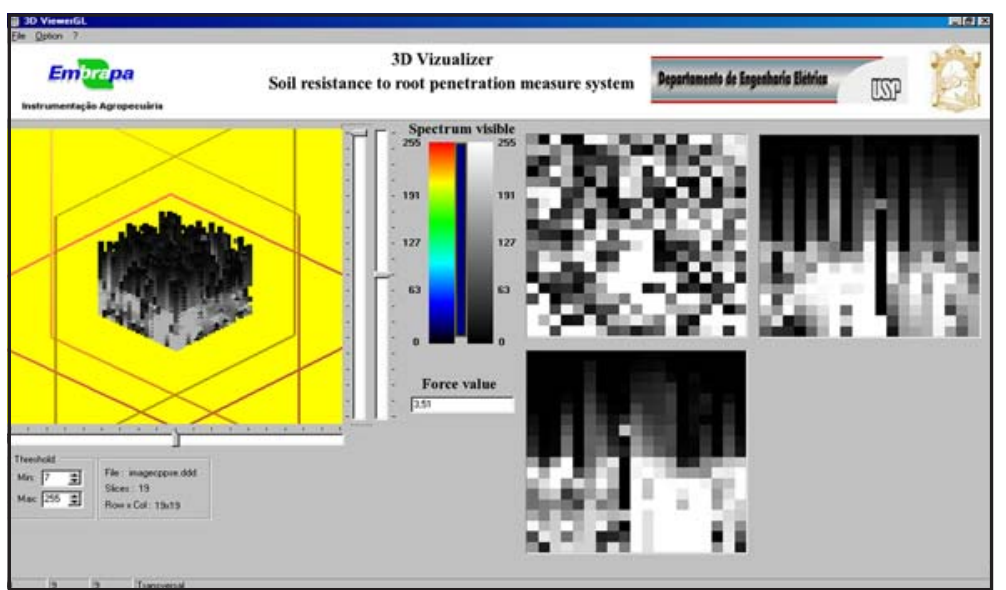

Figure 7 - Volumetric view of the soil resistance to root penetration in a block of soil sample in gray scale.

Table 1 - Field Trail - RSPR Measurement Coordinates

\begin{tabular}{|c|c|c|c|c|c|}
\hline \multicolumn{2}{|c|}{ Start coordinates } & \multicolumn{2}{|c|}{ End coordinates } & \multicolumn{2}{|c|}{ Increase } \\
\hline $\mathrm{X}(\mathrm{mm})$ & $\mathrm{Y}(\mathrm{mm})$ & $\mathrm{X}(\mathrm{mm})$ & $\mathrm{Y}(\mathrm{mm})$ & $\mathrm{X}(\mathrm{mm})$ & $\mathrm{Y}(\mathrm{mm})$ \\
\hline 0 & 0 & 270 & 270 & 15 & 15 \\
\hline
\end{tabular}

purpose of characterizing the field tests and due to a great number of data, the following coordinates were selected: $\mathrm{X}=255$ and $\mathrm{Y}=105$, in order to verify the soil resistance of the root penetration as represented in Figure 8.

For some depths, the force is equal to $0.0 \mathrm{~N}$, even for the readings conducted in the laboratory. This is due to the fact that the microprobe finds empty regions inside the sample. This occurs, for example, due to the presence of internal cracks or holes left by decomposed root material, ants, or other possible species of insects, or plants or natural pores. The sequence of representative two-dimensional maps generated in the tests can be observed in Figure 9.

For the test starting at the depth $\mathrm{z}=5.0 \mathrm{~mm}$, the beginning of a formation of a greater resistance area at the onset of the microprobe was observed, which could also represent plant roots.
The soil characteristics of the areas where the measurements were carried out have soil bulk densities according to the depth (Table 2). The volumetric soil resistance to root penetration obtained in the field test by two-dimensional maps and their frontal, sagittal and transverse planes, is shown in Figure 10.

\section{FINAL REMARKS}

The interface with the user is a user-friendly and viable tool for the analyses of soil resistance to root penetration as it can be seen in tables, graphs, or twodimensional and three-dimensional maps. It facilitates trial reports.

The linearity of the conversion process had a low error rate observed in the long-term. Thais involves the linearity of the tension relationship read as the duration of the mechanical force applied to the charge cell and the measurement of the soil resistance to penetration. In line with this perspective, the conversion values were equal to or above $0.16 \mathrm{~kg}$ of the error percentage. The average remained below 5\%. The instrument resolution is therefore characterized by $0.16 \mathrm{~kg}$ (15.4 N). 


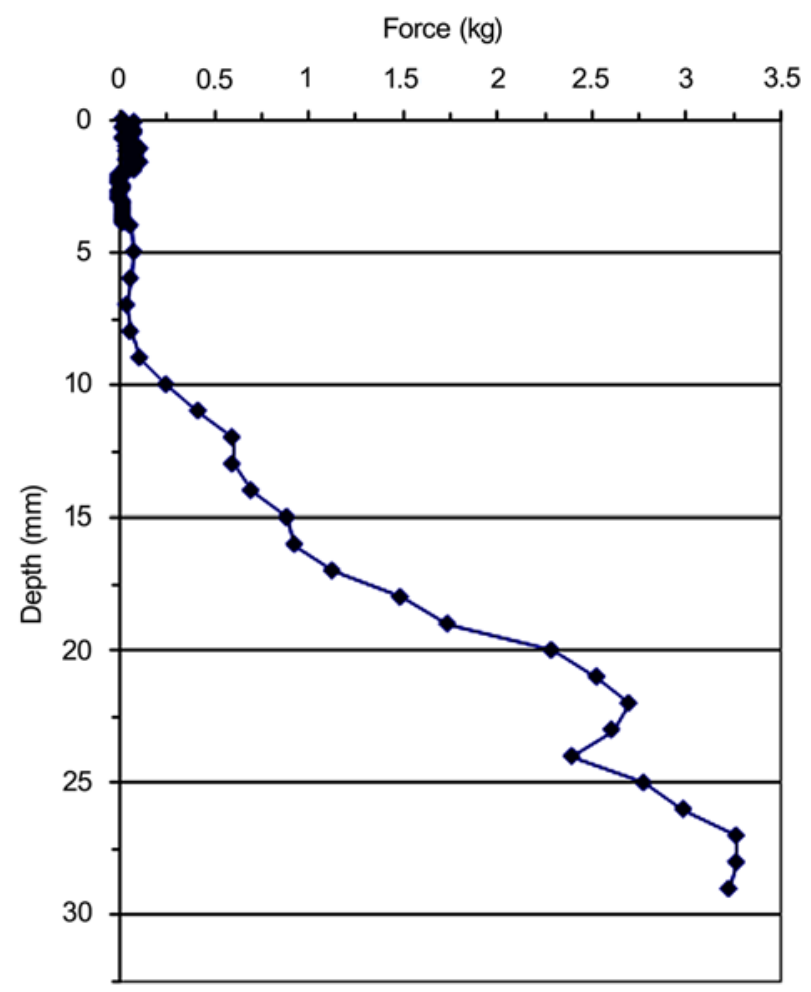

Figure 8 - Soil resistance variations to the root penetration in function of depth $\mathrm{Z}$ and coordinates $\mathrm{X}=255$ and $\mathrm{Y}=105$.

The average error percentage was $28.9 \%$ as found during the evaluation of the electronic perfection between the range of 0 to $0.10 \mathrm{~kg}$. This is attributed to the signal/noise of the operational amplifiers LM725 that are responsible for the adequate amplifier signal of the Wheatstone bridge in coordination with the load cell of the microprobe.

The instrument raises the level of variation flexibility of soil resistance to root penetration in a soil profile considering the location of the coordinates $(\mathrm{x}, \mathrm{y})$. Results are obtained in nearly real time in the form of a table or a graph as well as reports available on standard paper.

The generation of two-dimensional RSPR $\times$ Position maps showing the data depth demonstrates the potential of the system in evaluating soil resistance to root penetration in an environment that involves spatial variability, as well as making decisions based on the concept of agricultural precision. This potential can be seen for the soil profile, for laboratory samples, especially as a tool to facilitate decision making, taking into consideration real aspects of the heterogeneity, or the lack of it in case of soil samples that are not deformed.

The generation of RSPR $\times$ Position $\times$ Depth three-dimensional maps also demonstrates the
Table 2 - Soil density as function of the depth in the profile for the case study

\begin{tabular}{ll}
\hline Linear attenuation coefficient at $60 \mathrm{KeV}$ & $0.296 \mathrm{~cm}^{-1}$ \\
\hline Container number & 1.00 \\
\hline Sample thickness & $6.78 \mathrm{~cm}$ \\
\hline Data acquisition time & 90 seconds \\
\hline Sample length & $5.00 \mathrm{~cm}$ \\
\hline Measurements step & $0.50 \mathrm{~cm}$ \\
\hline Repetition & 1 \\
\hline Soil moisture $<\theta>$ & $9.83 \%$ \\
\hline Location & Density \\
\hline $\mathrm{cm}$ & $\mathrm{g} \mathrm{cm}{ }^{-3}$ \\
\hline 0.0 & 0.979 \\
0.5 & 1.194 \\
\hline 1.0 & 1.287 \\
\hline 1.5 & 1.256 \\
\hline 2.0 & 1.258 \\
\hline 2.5 & 1.212 \\
\hline 3.0 & 1.176 \\
\hline 4.5 & 1.273 \\
\hline 4.0 & 1.223 \\
\hline
\end{tabular}

potential of the system for the evaluation of soil resistance to root penetration in a field environment.

The option to use the Thread showed to be suitable for the application of Win32. By using an efficient synchronized system, even accessing critical areas of memory, the stability, repeatability and operational reliability of the system is guaranteed. The integration of the programming system with its different parts involves a control algorithm of the micro controller 80535 and the Win32 application. The use of Win32 enabled executing the necessary work of the instrument functions for soil resistance of root penetration measurements and visualization.

The present development of an instrument to facilitate decision making in processes that involve the evaluation of soil resistance to root penetration, constitutes a new and advanced tool that allows the analyses in nearly real time, including programming, spatial variability information as well as soil compaction observed in a natural or artificial laboratory environment, or directly in the field.

The results of the use of this instrument reduce the uncertainty of the measurement methods with respect to soil resistance to root penetration. This, therefore, is fundamentally important in optimizing risks in agricultural processes. 


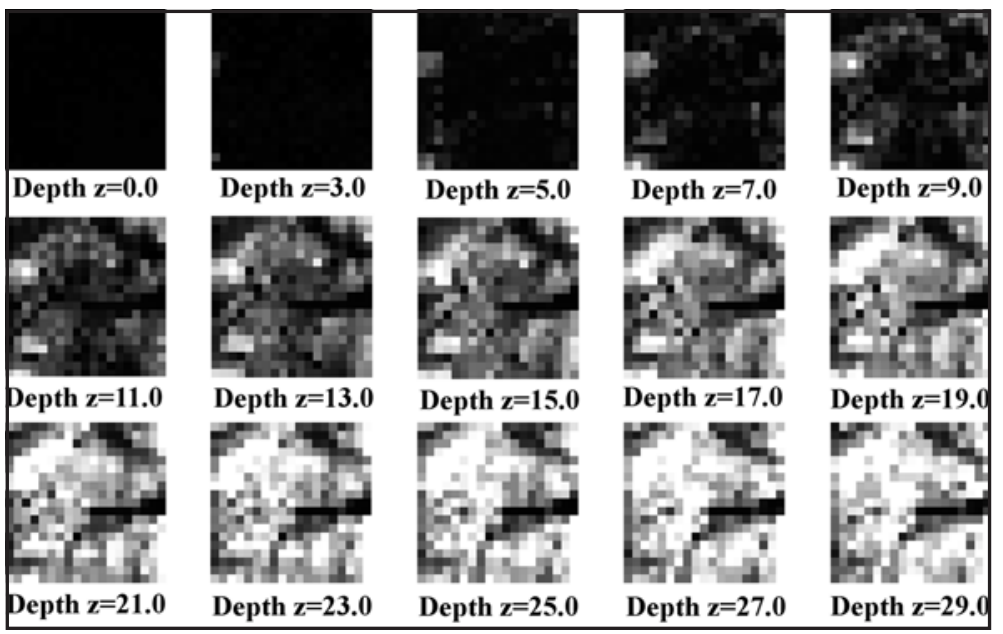

Figure 9 - Representative sequence of two-dimensional maps of the measurement of soil resistance to root penetration for the collected data with $\mathrm{Z}=0.0 \mathrm{~mm}, \mathrm{Z}=9.0 \mathrm{~mm}, \mathrm{Z}=17.0 \mathrm{~mm}, \mathrm{Z}=22.0 \mathrm{~mm}$, and $\mathrm{Z}=29.0 \mathrm{~mm}$.

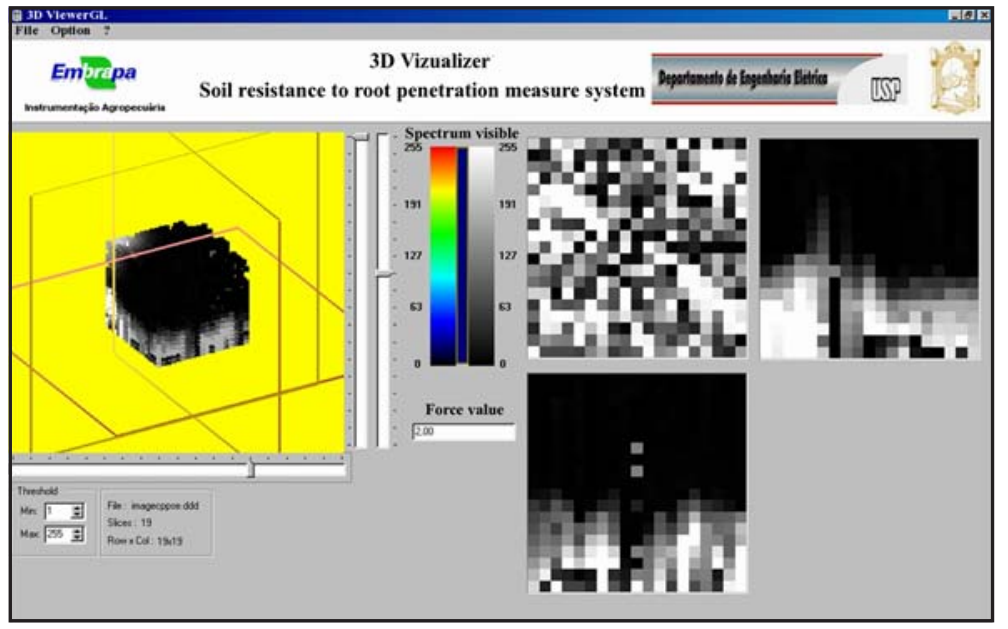

Figure 10 - Three-dimensional map of data of the soil resistance to root penetration collected in the field test.

\section{REFERENCES}

BARLEY, K.P.; FARRELL, D.A.; GREACEN, E.L. The influence of soil strength on the penetration of a loam by plant roots. Journal of Soil Research, v.3, p.69-79, 1965.

BRADFORD, J.M. Penetrability. In: KLUTE, A. (Ed.) Methods of soil analysis: physical and mineralogical methods. 2 ed. Madison: American Society of Agronomy, 1986. p.463-478. (Agronomy, 9).

BRADLEY, R.A.; DI CHRO, G. The FBI wavelet/scalar quantization standard for gray-scale fingerprint image compression. Los Alamos: Los Alamos National Lab, 1993. (Tech Report LA-UR-93-659).

CLIVATI-McINTYRE, A.A.; McCOY, E.L. Fractional Brownian description of aggregate surfaces within undisturbed soil samples using penetration resistance measurements. Soil and Tillage Research, v.88, p.144-152, 2006.

DONOHO, D. Nonlinear Wavelet Method for Recovery Signal, Densities and Spectra form Indirect and Noisy Data. In: DAUBECHIES, I. (Ed.) Different perspectives on wavelets. Providence: American Mathematical Society, 1993. p.173-205. (Proceeding of Symposia in Applied Mathematics, v.47).
DULEY, F.L. Surface factors affecting the rate of intake of water by soils. Proceedings of Soil Science Society of America, v.4, p.60-64, 1939.

GRANT, C.D.; KAY, P.H.; GROENEVELT, P.H.; KIDD, G.E. Spectral analysis of micropenetrometer data to characterize soil structure. Canadian Journal of Soil Science, v.65, p.789804, 1985.

GRAPS, A. An introduction to Wavelets. IEEE Computacional Science and Engineering, v.2, p.50-61,1995.

GROENEVELT, P.H.; KAY, B.D.; GRANT, C.D. Physical assessment of soil with respect to rooting potential. Geoderma, v.34, p.101-114, 1984.

HANKS, R.J.; THORP, F.C. Seedling emergence of wheat, as related to soil moisture content, bulk density, oxigen diffusion rate, and crust strength. Proceedings of Soil Science Society of America, v.20, p.307-310, 1956.

LINS E SILVA, M.L. Modelagem matemática na estimativa da densidade de um latossolo Vermelho escuro textur argilosa, pelo índice de cone. Campinas: Unicamp, 1999. 161 p. Tese (Doutorado).

LIU, Z.; SHI, B.; SHENG, D. A micropenetrometer for detecting structural strength inside soft soils. Geotechnical Testing Journal, v.29, p.443-450, 2006. 
MORIN, J.; BENYAMINI, Y.; MICHAELI, A. The effect of raindrop impact on the dynamics of soil surface crusting and water movement in the profile. Journal of Hydrology, v.52, p.321335, 1981.

RABELLO, L.M. Instrumentação avançada para tomada de decisão na avaliação da resistência do solo à penetração de raízes. São Carlos: USP/EESC, 2003. 184p. Tese (Doutorado).

REVATHY, K.; RAJU, G.; PRABHAKARAN, S.R.N. Image zooming by wavelets. Fractals, v.8, p.247-253, 2000.

ROLSTON, D.E.; BEDAIWY, N.A.; LOUIE, D.T. Micropenetrometerfor for in situ measurement of soil surface strength. Journal of Soil Science Society of America, v.55, p.481-485, 1991.
TAYLOR, H.M.; GARDNER, H.R. Penetration of cotton seedling taproots as influenced by bulk density, moisture content, and strength of soil. Soil Science, v.96, p.153-156, 1963.

WALDRON, L.J.; COSNTANTIN, G.K. Soil resistance to a slowly moving penetrometer. Soil science, v.109, p.221-226, 1970.

Received October 01, 2007

Accepted April 22, 2009 